Соколеиь I. I., ORCID ID: 0000-0002-4582-7082 дочент кафедри герлансьюої кандидат педагогічних наук, доцент, Київсьрсокоі фоілології ілені профбесора Г. Г. Почепиова Київського національного лінгвістичного університету

\author{
Ханикіна Н.В., \\ ORCID ID: 0000-0002-5920-9779 \\ кандидат фбілологічних наук, \\ старший науковий співробітник науково-дослідної лабораторї освітологї \\ Київського університету ілені Бориса Грінченка
}

\title{
МОТИВАЦІЙНА ОСНОВА ДІЕСЛІВ НА ПОЗНАЧЕННЯ ПСИХОЕМОЦІЙНОГО СТАНУ ЛЮБОВИКОХАННЯ В УКРАЇНСЬКІЙ ТА УГОРСЬКІЙ МОВАХ
}

\begin{abstract}
Анотація. У запропонованому дослідженні за мету поставлено аналіз дієслів на позначення психоемоційного стану закоханості суб' єкта в українській та угорській мовах, визначення ядерних і периферійних зон ситуатем, що позначають стан закоханості суб'єкта в українській та угорській мовах, встановлення мотиваційної основи дієслів на позначення психоемоційіного стану закоханості суб'єкта в українській та угорській мовах.

Завданням роботи є виявлення характеру мотиваційних відношень в ономасіологічній і когнітивно-семантичній структурі дієслів, що позначають психічний стан закоханості/любові суб'єкта, а також здійснення когнітивно-ономасіологічного аналізу дієслів на позначення цього психоемоційного стану суб'єкта і виявлення типів їх мотивації в українській та угорській мовах.

У роботі здійснено поліситуаційний аналіз, який дає змогу всередині лексико-семантичної групи дієслів, що позначають психоемоційний стан суб'єкта, а саме стан закоханості, в українській та угорській мовах встановити зони ядерної семантики та його периферії, а саме ближньої, дальної, крайньої. В основі запропонованої методики лежить план вираження дієслова як поліситуаційної, поліподієвої, поліпропозиційної структури, що дає можливість представити семантику дісслова у вигляді ситуатеми як особливої структури, яка відображає динаміку дієслівного змісту.
\end{abstract}

У ході дослідження дієслів на позначення психоемоційного стану закоханості/любові суб'єкта в українській та угорських мовах було встановлено їх етимологічне походження та визначено ядерні позиції: асертема - ситуатеми, ситуатеми ближньої, дальньої та крайньої периферій, конситуації. Згідно з поліситуаційним дієслівним аналізом та визначенням ядерно-периферійної зони ситуатем були встановлені типи мотиваційної основи для дієслівної семантики любові. У зіставному аспекті висвітлено спільні та відмінні ознаки в номінуванні та мотивації для дієслів перехідного типу від психоемоційного стану до фізіологічно-тілесного стану суб'єкта.

В результаті дослідження були виявлені типи мотивації психоемоційного стану закоханості/любові суб'єкта в українській та угорській мовах, зокрема змішаний тип мотивації, у якому перехрещуються модусний сенсорно-психологічний тип мотивації і гештальтний різновид асоціативно-термінальної мотивації з домінантною сублімованою (естетичною та етичною) позитивною оцінкою.

Ключові слова: вербальна семантика, поліситуаційний аналіз, асертема, ближня, дальня, крайня периферії, конситуація, ситуатема, ситуативно-подієво-пропозиціональний підхід.

Постановка проблеми. Питання зіставлення двох генетично неспоріднених мов, але близьких територіально української та угорської - $€$ актуальним з огляду на лексичне наповнення слів. Ці мови належать не тільки до різних мовних сімей - індоєвропейської та фіно-угорської, - але й до різних мовних типів - флективного та аглютинативного. Протягом тисячолітнього сусідства мови зазнали чималого впливу: угорська мова має у своєму складі 20\% запозиченої лексики зі слов'янських мов, українська мова має лексичні запозичення, якими активно послуговується: це назви страв, одягу, інструментів, частин тіла, родинні позначення (гулям, паприка, куліш, кучма, лаба, тазда, легінь тощо), серед запозичень є лексеми, які вказують на психоемоційний стан людини (банувати).

Аналіз останніх досліджень і пуб̆лікацій. Вивченню емотивної лексики присвячено доволі багато робіт у науковій літературі, зокрема в історико-етимологічних розвідках (Ю.І. Гамаюнова), у німецькій мові (М.В. Гамзюк), у сучасному мовознавстві (Н.С. Штефанюк), у художніх та наукових текстах (Б.В. Стельмах), у творчості митців слова (Н.О. Позднякова), в українській та американській культурах (С.М. Мандер). Меншою мірою науковці торкаються вивчення емотивної лексики угорської мови.

Метою статті $€$ визначення мотиваційної основи дієслів на позначення психоемоційного стану закоханості людини шляхом установлення лексико-семантичних ядерних і периферійних зон ситуатем в українській та угорській мовах. Об'єктом дослідження послугували словникові статті 3 реєстровими дієсловами із семантикою психічного стану закоханості/любові суб'єкта в тлумачних та фразеологічних словниках української та угорської мов.

Виклад основного матеріалу. Проблема встановлення мотиваційної основи для дієслів любити/кохати, що познача- 
ють психоемоційний стан суб'єкта у двох аналізованих мовах, а саме українській та угорській, вирішується у статті за допомогою поліситуаційного аналізу мотивації дієслівної семантики [17, с. 185-202], який був запропонований сучасними науковцями.

У науковій літературі останніх десятиліть зарекомендував себе ситуаційно-подієво-пропозиційний підхід до аналізу дієслів, що був розроблений Н.Б. Лебедєвою [4, с. 95-108; 5; 6, с. 183-187; 7; 8, с. 92-97] та іiі послідовниками, а саме М.С. Небольсиною [9, с. 8-13; 10, с. 71-74; 11, с. 120-125] та С.Л. Камзіною [3]. Питанням установлення мотиваційної основи, зокрема дієслів, активно займається український науковець 0.0. Селіванова [12, с. 379-389], яка продовжила досягнення у сфері когнітивної семантики (М.М. Болдирев, Дж. Лакофф, М. Тернер) та запропонувала такі чотири типи мотивації на основі концептуального місця мотиватора в ментально-психонетичному комплексі.

1) Пропозиційна мотивація, яка оперує знаками-мотиваторами в прямих значеннях буквальної інформації про позначене в межах однієї ситуації, як правило, асертивної, ядерної (у термінології Н.Б. Лебедєвої). Цей тип мотивації за загальним механізмом розглядається як метонімічний, адже в процесі номінації здійснюється перенесення позначень одного компонента події на інший, імені класу об'єктів на об'єкт цього класу, позначення частини на ціле й цілого на частину за суміжністю [12, с. 163].

2) Асоціативно-термінальна мотивація, що вибирає мотиватори метафоричного статусу на підставі аналогічних зв' язків з іншими концептуальними сферами свідомості, такими як конситуації формування ближньої і дальної периферії дієслівного значення (асоціативно-термінальна мотивація, спрямована на використання в процесі найменування фрагмента неістинних (необ'єктивних, нетривіальних) знань про позначуване, який корелює 3 певними диктумними позиціями, що в такому разі $€$ знаково нульовими [12, с. 172]).

3) Модусна мотивація, яка грунтується на оцінці носіями мови знаку мотиватора в кореляції з психічними функціями відчуттів, почуттів, архетипами позасвідомого [12, с. 169].

4) Змішана мотивація, яка суміщає мотиватори, вибрані з різних фрагментів структури знань (асертивної ситуації і конситуацій) про позначене. Особливістю цього типу мотивації $€$ те, що одна ономасіологічна ознака вибирається з предикатно-аргументної частини й відображає істинну інформацію про об'єкт номінації, одержану в процесі пізнавально-практичної діяльності номінаторів, а друга - 3 термінально-асоціативної сфери чи модусу і репрезентує зв'язки між предметними сферами [12, с. 175].

Цікаво, що до сфери психіки та емоцій людини належить одне 3 найсильніших вихідних почуттів, а саме любов, яку характеризують через емоції інтересу й радості. Любов - це патерн позитивних емоцій, проте на тлі міжособистісних стосунків любов може включати негативні емоції, такі як печаль, гнів, страх. Виокремлюють материнську, сиблінгову, романтичну любов. Основні ознаки цих типів любові визначаються на соціально-психологічному рівні. Йдеться про прив'язаність, вірність, відданість, бажання захищати кохану людину й піклуватися про неї [2, с. 410-425]. Любов постає у двох іпостасях, а саме позитивній і негативній, двох царинах, а саме психічній і соціальній.
Емоція любові в українській мові концептуалізується ситуатемами ЛЮБИТИ, КОХАТИ, одиницями плану змісту яких є дієслова любити, кохати. Словник української мови в 11 томах (далі - СУМ) витлумачує ці лексеми як синонімічні одиниці зі значеннями «відчувати глибоку відданість, прив'язаність до кого-, чого-небудь» та «почувати, виявляти глибоку сердечну прихильність до особи іншої статі»: Як я люблю тебе, мій рідний краю, Як я люблю красу твою, твій люд (Іван Франко, ХІІІ, 1854, 324); *Образно. Мати повивала Мене малого і вночі На свічку богу заробляла; Пречистій ставила, молила, Щоб доля добрая любила їі дитину (Тарас Шевченко, II, 1853, 110). Коли вподобав Олену, бери Олену, а мені кожна невістка буде люба, аби тебе кохала, мій сину (Марко Вовчок, I, 1855, 51); [Маруся:] Як-то чудно у світі діється, що, кого щиро кохаєш, - одвертається від тебе та ще й кепкує, зневажає; кого ж ненавидиш, дивиться на його не хотіла б - у вічі лізе! (Марко Кропивницький, I, 1858, 89); Так ніхто не кохав. Через тисячі літ лиш приходить подібне кохання (Володимир Сосюра, I, 1857, 67). Хто кохав життя ледаче, Непереливки тому (Леонід Глібов, Вибр., 1857, 120). Добра донька дуже кохала свого батька (Михайло Коцюбинський, III, 1856, 8) [14, с. 313].

Ситуатеми ЛЮБИТИ, КОХАТИ вербалізовані у численних синонімах, окремі з яких набули фразеологізації разом 3 правобічними синтаксемами обожнювати, обожувати, боготворити, божествити, жалувати, улюбляти, дихати ким, чим, полюбляти розм., долюблювати розм., долюбляти розм., улюбляти [влюбляти] розм., навидіти діал., умирати [вмирати], пропадати за ким, розм. (дуже сильно); сохнути за ким, розм. (страждаючи).

Слід зазначити, що лексема кохати тотожна лексемі любити у другому значенні згідно із з СУМ: «виявляти глибоку сердечну прихильність до особи іншої статі». Енея так вона любила, Що аж сама себе спалила (Іван Котляревський, I, 1852, 86). Мокрина довго любила його та все давала гарбузи своїм женихам (Нечуй-Левицький, II, 1856, 249). У значенні «бути закоханим» вона виступає в таких прикладах. Сиділа [дівчина] до самої ночі перед вікном і втирала Заплакані очі, Бо й вона таки любила; I страх як любила! (Тарас Шевченко, II, 1853, 157). Вміє розставатись той, хто вмів любить (Максим Рильський, I, 1860, 129) [14, с. 562]. Тобі дано і вірити й кохати. А щзо мені? Які такі куші?! (Ліна Костенко «Маруся Чурай») [16].

Мотиваційною ознакою для дієслів любити, кохати послугували, згідно 3 версіями Етимологічного словника української мови (далі - ЕСУМ), такі слова: д-інд *leubh «жадати, збуджувати бажання», алб. laps «бажаю, жадаю», лат. libet «у мене є бажання», лит. liaupse «похвала; похвальна пісня», i-є. *kos-/kes- «чесати, скребти», лат. comis «ласкавий, послужливий», лит. kakti «досягати». Лексеми вказують на бажання суб'єкта до задоволення, що стало мотивом для дієслівних номінацій [1, с. 318].

Конситуаціями (ближньої периферії) є суміжні ситуації стану любові, які представлені цими двома лексемами, актуалізовані на ментальному рівні носіїв української мови та позначені в семантиці вищезгаданих дієслів: обожнювати, обожувати, боготворити, божествити, жалувати, улюбляти, дихати, полюбляти, долюблювати, долюбляти, улюбляти [влюбляти], навидіти, умирати [вмирати], пропадати, сохнути. 
Приклад речення 3 вербативом кохати (Коли вподобав Олену, бери Олену, а мені кожна невістка буде люба [буду любити], аби тебе кохала, мій сину (Марко Вовчок, I, 1855, 51) [14, с. 562]) демонструє гештальтний тип мотивації з позитивним полюсом сенсорно-психологічної оцінки, адже тут механізм перенесення значення у дієслова кохала є когнітивно-метафоричним, оскільки мотиватором виявлення семантики кохання $є$ знак вподобав, що належить до інших концептуальних сфер, а саме інтересу, радості. Саме мотивація дає змогу розмежувати в українській мові гіперо-гіпонімічні відношення (відтінки) у значеннях синонімічних лексем любити, кохати: 1) відчувати глибоку відданість, прив'язаність до кого-, чого-небудь; 2) почувати, виявляти глибоку сердечну прихильність до особи іншої статі.

Тотожність значень спостерігаємо зі словоформами з постфіксами -ся: любитися, кохатися. Кохайтеся ж, любітеся, Як серденько знає (Тарас Шевченко, I, 1851, 49). [Сокуренко:] Невже ви не знаєте, що ми з Оксаною любимось вже більше року? Ви ж самі, дивлячись на наме кохання, радувались (Марко Кропивницький, I, 1858, 128). Страшно. Увесь вік свій дівувати, Ні з ким не кохатись (Тарас Шевченко, II, 1863, 164). Сходились коло иеркви, або десь у лісі, щоб стариня не знала, як кохаються діти ворожих родів (Михайло Коцюбинський, II, 1855, 313). *Образно. Кохаюся з лихом, привіту не знаю (Пісні та романси українських поетів, II, 1856, 30). Як будеш з правдою кохаться, то не будеш і паном зваться (Українські народні прислів'я та приказки, 1855, 63) [14, с. 314].

Конситуації (ближньої периферії) виражені в супровідних вторинних позначеннях ситуатем любити, кохати. «Бути закоханим» - Сиділа [дівчина] до самої ночі перед вікном і втирала Заплакані очі, Бо й вона таки любила; I страх як любила! (Тарас Шевченко, II, 1853, 157). Вміс розставатись той, хто вмів любить (Максим Рильський, I, 1860, 129). У мовленні «бути в інтимних стосунках з особою іншої статі» - Буржуа i кардинал Справляють свій останній бал <...> їм тільки б жити в пишних залах, Жінок любити, пить, гулять (Володимир Сосюра, I, 1857, 461). Він любиться з молодииями <...> я доведу, що він ходить до тої слинявої Насті (Михайло Коцюбинський, I, 1855, 38). Любилася я з моїм так, що швидко вже почала сподіватися на вагітність (Юрій Яновський, II, 1858, 105) $[14$, c. 562].

Ближню периферію становлять конситуації, які перехрещуються з концептуальною сферою IНТЕРЕС. «Мати інтерес, потяг до чого-небудь» - Всі вони позвикали робить влітку на полі, на вольному повітрі; всі любили хліборобство (Нечуй-Левицький, II, 1856, 214). Терентій любить пісню і сам уміс з душею співати (Михайло Стельмах, I, 1862, 48). Він любив завод $i$ знав його досконало, до найменших деталей (Вадим Собко, Біле полум'я, 1852, 100. Я страменно люблю читати, - казав я, різні книжки (Юрій Яновський, II, 1858, 70) [14, с. 562].

Розширені значення ситуатем любити, кохати також становлять поле ближньої периферії. «Високо цінувати що-небудь, віддавати перевагу чомусь»: Добре жить Тому, чия душа i дума Добро навчилася любить! (Тарас Шевченко, II, 1853, 189). Світлий народе, в блакить ти прокладаєщ путі <...> Як же мені не любить руки твої золоті! (Володимир Сосюра, Близька далина, 1860, 7). Я поспішаю на роботу <...> Я день люблю, бо день - це труд (Микола Руденко, Поезії, 1849, 106). «Відчувати задоволення від чого-небудь»: Не кажіть мені про те [найми], не люблю. Я й в мислі не мав такого (Михайло Коцюбинський, II, 1855, 17). [Платон:] Я люблю складні операиії. Хірург мусить бути озброєним (Олександр Корнійчук, I, 1855, 98). Люблю, коли в вікно розкрите шумлять безжурно дерева (Володимир Сосюра, II, 1858, 143). Він не любив, щоб хтось був свідком його хвилювань (Яків Баш, Вибр., 1848, 121). «Мати нахил, пристрасть до чого-небудь»: Горпина не їла вона змалку не любила молочної каші (Панас Мирний, I, 1854, 291). Сагайда < ...> любить - заради розваги - всією п'ятірнею проводити Маковейчикові од лоба до підборіддя (Олесь Гончар, III, 1859, 55) [14, c. 562].

Ближня периферія ситуатем любити, кохати представлена значеннями, що позначають емоцію з боку не тільки закоханості, але й товариської симпатії зі значенням «відчувати глибоку повагу, товариську відданість одне до одного»: Пилипиха була ще давня товаришка і приятелька нашій матері, і жили вони $<$...> добре, любилися (Марко Вовчок, I, 1855, 183). «Добре ставитися одне до одного, шанувати, не кривдити одне одного»: Чули заповідь господню: Всім любитися, А не рить другим безодню Та злобитися! (Павло Грабовський, I, 1859, 117). «Почувати одне до одного глибоку приязнь, викликану родинними зв'язками»: Ми з братом щчиро любилися зроду, змалку (Марко Вовчок, I, 1855, 4). Рідше «бути до вподоби кому-небудь»: Ненечка ї̈ Амата В душі своій була строката: Не всякий ій любився зять (Іван Котляревський, I, 1852, 165) [14, с. 563].

Дальню периферію ситуатем любити, кохати демонструють фраземи, які більшою мірою пов'язані 3 душею, духом, тобто належать до міфологічної сфери розкриття свідомості: душі не чути в кому; дух ронити за ким, рідко (виявляти закоханість до кого-небудь, намагаючись невідступно бути поряд), а також фраземи зорової концептуальної сфери: сліпма упадати за ким. Душі в доньиі не чув, думав онуків за ручку водити, а тепер маєте (Панч, 4, 1882, с. 131). Мало коли й дома сидии - як те перекотиполе, все гуляєш. Я за тобою й дух роню, а ти мене забиваєщ (Грінченко, 2, 1863, с. 368). Парубки за нею сліпма упадають, а ій тілько б жартувать! (Карпенко-Карий, 1, 1860, с. 187) [14, с. 562].

Ядро ситуатеми SZERET в угорській мові представлено дієсловом szeret, що вказує на значення «людина відчуває любов до когось, рідше чогось»; ніжні почуття; прояв любові: Oh Pistikám, szeresd, tiszteld, imádd (Petöfi Sándor). Hát itt hagynál minket, sok derék cselédet, Kik mint gyermekünket, úgy szerettünk téged? (Arany János). Різновидом цього почуття є таке: «любити егоїстично, проявляти самолюбство, вигоду, власний інтеpec»: önzö módon mindig csak a maga hasznát, a maga érdekeit keresi, önmagának igyekszik megszerezni az élet minden javát; Aki szeret, nem él hiába. / Új szivïnk nöjjön, Ne gyülöljön, ne sértsen, Szeressen, csak szeressen (Tóth Árpád) [18].

Ближню периферію становить ситуатема зі значенням «любити когось», а саме відчуттям закоханості, що вказує на отримання жаданого, того ідеалу, на який очікував/ла: Én ugyan szeretlek (Petöfi Sándor). Téged szeretlek, Te vagy, akit vártam (Ady Endre) [18].

Значення «перебувати в любові, відчувати почуття любові» з безгріховністю, відвертістю також належить до ближньої периферіï: Szeretni nem bün. Öszintén, igazán szeret. Csak egyszer szeretett életében. / Jónás szeretett. Elöször életében igazán (Eötvös József). Ki szeret s párra nem találhat, | oly hontalan, | mint amilyen gyámoltalan $\mid$ a vadállat (József Attila) [18]. 
У простонародному стилі евфемізм зі значенням «любити/ хотіти/бажати когось, мати любовний роман» теж перебуває у наближеній зоні до ядра: Régen szereti, gyereke is van töle [18].

Доповнюе ближню периферію значення «у комусь міститься те, за чим/ким (не)йдуть інші, (не)тягнуться, (не) наслідують»: Szereti a nőket. Nem szeretik a lyányok. / Szép legény volt Marci, szerették a lyányok (Petőfi Sándor). [A zágoni lányok] nem szeretik ám az olyan legényt, aki nagyon alvós [sokat alszik] (Móra Ferenc) [18].

У зону ближньої периферії входить ситуатема зі значенням «любити когось, уподобати» (до вподоби, подобається): Szereti a vidám embereket. Szereti a lírai költőket. / Szeret Oly költöt, aki versben szónokol! (Arany János, Арістотель, переклад) Szeretem Hervadva ha vágynak, a nöket (Ady Endre) [18].

Ситуатеми 3 експресивним забарвленням «любити когось 3 приємністю, із солодким відчуттям всередині, смакуючи, притягуючись, подобатися» оточують ядро аналізованого дісслова: Szereti a kutyákat, a lovakat, szeret vmilyen ételt v. italt; szereti a szépet; szereti a zenét. Nem szereti a durva tréfákat. Föképp azt szeretem benne, hogy; Vegyetek, ki mit szeret! Nem tudni, mit szeret rajta. У приказках: Szereti, mint A kecske a kést. / [Az öszt] Tudja isten, hogy mi okból Szeretem? de szeretem (Petőfi Sándor). Fejét rázta Miklós, ahol nem szerette [a beszédet] (Arany János). Szeretem a beteg rózsákat < ..> A sugaras, a bánatos Ösz-időket (Ady Endre). A cselédek kérem, nem is merik szeretni azt, amit szeretnek. Hát elhitetik magukkal, hogy nem is jó az, ami jó (Kosztolányi Dezsö). Сюди ж входить фамільярний вираз у значенні «надати мені задоволення»: Szeretem: örülök neki, hogy úgy van v. igy történt, tetszik nekem; kedvemre való, helyesnek tartom. Ezt már szeretem!: ez igen, ez már teszi, ennek van értelme! Szeretem, hogy elmondtad. Öszinte voltál, ezt szeretem. / Olyan férfi vagy, minővel Szerettem, hogy közöm volt valaha (Arany János, Шекспір, переклад). Öcsém te, ... de szeretem, hogy látlak (Tolnai Lajos) [18].

Розширює зону периферії ситуатема зі значенням «особисто комусь подобається, виконувати щось із задоволенням, охоче й часто, звично»: Nem szeret senkit se bántani. Nem szeretek vele vitatkozni. / Pfuj! Nem szeretek én körmölni (Mikszáth Kálmán). Korán szokott fölkelni, és szeret az ablakban állni, mert a reggeli levegö éltetö erejü (Gárdonyi Géza). Szeretem megcsókolni azt, Aki elmegy (Ady Endre) [18].

Наповнює периферію простонародна структура зі значенням «із задоволенням залишитися, затриматися»: Szeretsz Pesten? Nem szeretek itt. / Ott van a kis szülöi házunk Hát nem szeretsz-e ottan? (Jókai Mór) Odafenn nem szerettél köztük (Justh Zsigmond) [18].

Ситуатема 3 умовним способом зі значенням «хотіти чогось, до вподоби щось, бажати щось» також перебуває у зоні периферії: Szeretne egy pontosan járó órát. Mit szeretnél születésnapodra? [18].

Велика кількість віддієслівних/відінфінітивних іменників та прикметників, що походять від ядерного дієслова szeret, вказують на значення «мати свої бажання, бажання отримати щось, бажання бути в змозі зробити що-небудь»: Az az óhajtása, vágya, kivánsága, hogy csinálhasson vmit, v. történjék vele vmi. Szeretne jobb álláshoz jutni; szeretne utazgatni; szeretne világosabban látni, megérteni vmit; szeretném tudni: gyak. fenyegetô számonkérésként: kiváncsi vagyok rá; (azt) szeretném én és látni; nem szeretnék a börében lenni. Szerette volna megcsókolni örömében. / Lelkem múlatni szeretne Még veletek kedves hiveim (Petöfi Sándor). Szeretném magam megmutatni, Hogy látva lássanak (Ady Endre). Szeretném azt látni, hogy téged valaki ne hagyjon tanulni! (Móricz Zsigmond) Szeretné: azt kivánja v. követeli. Szeretném, ha ez többé nem fordulna elö! Szeretném, ha ezt tudomásul vennétek! [18].

Значення дісслівних лексем на позначення любові в українській та угорській мовах

\begin{tabular}{|c|c|c|}
\hline & Любити -кохати & Szeret \\
\hline Ядро дієслова & $\begin{array}{l}\text { - «Почувати, виявляти глибоку сердечну прихильність до } \\
\text { особи іншої статі»; } \\
\text { - «відчувати глибоку відданість, прив’язаність до кого-, } \\
\text { чого-небудь»; } \\
\text { - «відчувати сердечну прихильність до родинно близьких } \\
\text { осіб (дітей, матері та інших)». }\end{array}$ & $\begin{array}{l}\text { - } \quad \text { «Відчувати любов до когось, рідше чогось; ніжність»; } \\
-\quad \text { «любити егоїстично, або з вигодою»; } \\
\text { - } \quad \text { «любити, отримуючи користь». }\end{array}$ \\
\hline $\begin{array}{l}\text { Ближня периферія } \\
\text { дієслова }\end{array}$ & $\begin{array}{l}\text { - } \quad \text { “Почувати, виявляти глибоку сердечну прихильність до } \\
\text { особи іншої статі»; } \\
-\quad \text { «бути закоханим»; } \\
-\quad \text { «мати інтерес, потяг до чого-небудь»; } \\
-\quad \text { «бути в інтимних стосунках з особою іншої статі»; } \\
-\quad \text { «високо цінувати що-небудь, віддавати перевагу чомусь» } \\
-\quad \text { «відчувати задоволення від чого-небудь»; } \\
-\quad \text { «відчувати глибоку повагу, товариську відданість одне до } \\
\text { одного»; } \\
-\quad \text { «добре ставитися одне до одного, шанувати, не кривдити } \\
\text { одне одного»; } \\
-\quad \text { «почувати одне до одного глибоку приязнь, викликану } \\
\text { родинними зв’язками»; } \\
-\quad \text { «бути до вподоби кому-небудь». }\end{array}$ & $\begin{array}{l}\text { - } \quad \text { «Любити когось, тобто відчувати закоханість, отримувати } \\
\text { жадане, той ідеал, на який очікував/ла»; } \\
-\quad \text { «переживати відчуття любові»; } \\
-\quad \text { «любити безгріховно, відверто»; } \\
-\quad \text { «любити/хотіти/бажати когось, мати любовний роман»; } \\
-\quad \text { «любити за те, що є або немає в інших, за чим/ким (не)йдуть } \\
\text { iнші, (не)тягнуться, (не)наслідують»; } \\
-\quad \text { «любити когось, уподобати»; } \\
-\quad \text { «любити когось з приємністю, із солодким відчуттям всередині, } \\
\text { смакуючи»; } \\
-\quad \text { «отримувати задоволення»; } \\
-\quad \text { «подобатися комусь особисто, виконувати щось із задоволенням, } \\
\text { охоче й часто, звично»; } \\
-\quad \text { «із задоволенням залишитися, затриматися»; } \\
-\quad \text { «хотіти чогось, мати до вподоби щось, бажати щось»; } \\
-\quad \text { «мати свої бажання, бажання отримати щось, бажання бути в } \\
\text { змозі зробити що-небудь»; } \\
-\quad \text { «любитися/кохатися з кимось, мати любовний роман з кимось } \\
\text { одруженим»; } \\
-\quad \text { «проявити ласку, поцілувати, розгорнути обійми, показати свою } \\
\text { любов». }\end{array}$ \\
\hline $\begin{array}{l}\text { Дальня периферія } \\
\text { дієслова }\end{array}$ & $\begin{array}{l}\text { Фраземи, які більшою мірою пов’язані з душею, духом, тобто } \\
\text { належать до міфологічної сфери, а також фраземи зорової } \\
\text { концептуальної сфери. }\end{array}$ & $\begin{array}{l}\text { Ідіоми зі вказівкою на місце любові в житті дітей, народу, можуть } \\
\text { межувати із зацікавленістю. }\end{array}$ \\
\hline
\end{tabular}


Ситуатема SZERETKEZIK вказує на контакт із кимось («любитися/кохатися з кимось, мати любовний роман з кимось одруженим»): A fui megint csókolta leányt, és a diványra hanyatlottak $<\ldots>$ szeretkeztek < ... buja szemérmetlenséggel (Nagy Lajos) [18].

Застаріле значення, що передається ситуатемою «проявити ласку, поцілунок, розгорнути обійми, показати свою любов», виражене у такому прикладі: Magyar ember nem szeret mások elött szeretkōzni, még a feleségével sem (Jókai Mór) [18].

Ідіоми зі вказівкою на місце любові в житті дітей, народу, iз перенесенням на зацікавленість складають дальню периферію угорської ситуатеми SZERET: Szeressük egymást gyerekek! (békességre, szeretetre való biztatás kifejezése: a béke, a szeret a legfontosabb dolog a világon); szeret a mások háza elött seperni szeret a mások dolgával, hibáival törödni, szivesen megszól másokat, noha ö sem jobb náluk, szerét ejti alkalmat, módot talál vmire (vminek) [19].

Ядерні та периферійні значення дієслівних лексем на позначення любові в українській та угорській мовах представлені в табл. 1.

Аналіз зіставлення лексем любити/кохати в українській мові та szeret в угорській мові в лексикографічній та художній літературі засвідчив, що аналізовані лексеми мають більше розбіжностей, аніж схожих позначень як у якісних, так і в кількісних показниках. В українській мові лексикосемантичні позначення не фіксують внутрішніх негативних відчуттів стосовно любові чи морально-етичних заборон, а саме егоїзму, користі, любовного роману з одруженим/ою, також не вказують на насолоду в стані любові, бажання отримати щось. У позитивному сенсі лексичні позначення у двох аналізованих мовах демонструють прояв інтересу, зацікавленості у комусь, чомусь.

Висновки. Поліситуаційний аналіз дав змогу встановити тип мотивації для дісслів психоемоційного стану закоханості любити/кохати. Мотиваційною основою дієслівної семантики любові $є$ змішаний тип мотивації, в якому перехрещуються модусний сенсорно-психологічний тип мотивації і гештальтний різновид асоціативно-термінальної мотивації 3 домінантною сублімованої (естетичної та етичної) позитивної оцінки. Метафоричними мотиваторами 3 позитивним модусом оцінки $є$ гештальти зорових, смакових і міфологічних концептосфер в обох мовах.

У подальшому планується проаналізувати психоемоційні стани радості та суму суб̄'єкта як корелятів.

\section{Jimepamypa:}

1. Етимологічний словник української мови : у 7 т. / за ред. О.С. Мельничука. Київ : Наукова думка, 2012. Т. 6 : Р-Т. 586 с.

2. Изард К.Э. Психология эмоций / пер. с англ. В.В. Мисник, А.М. Татлыбаева. Санкт-Петербург : Питер, 2008. 464 с.

3. Камзина С.Л. Полиситуативный анализ как метод описания семантико-деривационных отношений внутри лексико-семантической группы глаголов создания художественного образа. Вестник Кемеровского государственного университета. Языкознание. URL: https://cyberleninka.ru/article/n/polisituativnyyanaliz-kak-metod-opisaniya-semantiko-derivatsionnyh-otnosheniyvnutri-leksiko-semanticheskoy-gruppy-glagolov (дата звернення: 02.12.2020).

4. Королева Ю.В., Лебедева Н.Б. Ситуатемный анализ глагольной семантики как разновидность когнитивного подхода. Сибирский филологический журнал. 2004. № 3-4. С. 95-108.
5. Лебедева Н.Б. Полиситуативность глагольной семантики (на материале русских префиксальных глаголов). Томск : изд-во Томского университета, 1899.

6. Лебедева Н.Б. Ситуатема и текст. Человек - коммуникация текст. Вып. 4 / под ред. А.А. Чувакина. Барнаул : изд-во Алтайского университета, 2000. С. 183-187.

7. Лебедева Н.Б. Полиситуативный анализ глагольной семантики / отв. ред. О.И. Блинова. 2-е изд., испр. и доп. Москва : Книжный дом «ЛИБРО-КОМ», 2010.

8. Лебедева Н.Б. Многослойность лексической семантики и ситуатема как полиситуативная структура. Вестник Челябинского государственного университета. Филология. Искусствоведение. 2012. Вып. 63. № 5 (259). С. 92-97.

9. Небольсина М.С. Полиситуативный анализ семантики глаголов в контексте когнитивных исследований. Вестник Барнаульского государственного педагогического университета. Серия: Гуманитарные науки. 2002. № 2. С. 8-13.

10. Небольсина М.С. Ситуатемы глаголов речи как единицы полиситуативного описания языковой картины мира (на материале русского и немецкого языков). Картина мира: модели, методы, конuелты : материалы Всероссийской междисциплинарной школы молодых ученых «Картина мира: язык, философия, наука» / под ред. 3.И. Резановой. Томск : изд-во ТГУ, 2002. С. 71-74.

11. Небольсина М.С. Полиситуативный анализ глаголов речевого воздействия в ономасиологическом аспекте. Вестник Барнаульского государственного педагогического университета. Серия: Гуманитарные науки. 2005. № 5. С. 120-125.

12. Селіванова О.О. Когнітивна концепція словотвірної мотивації. Проблеми загального, германського та слов'янського мовознавства : до 70-річчя професора В.В. Левицького. Чернівці : Книга XXI, 2008. С. 379-389.

13. Селиванова Е.А. Когнитивная ономасиология. Киев : Фитосоциоцентр, 2000. $248 \mathrm{c}$.

14. Словник української мови : в 11 т. / за ред. І.К. Білодіда. Київ : Наукова думка, 1873. Т. 4 : I-M. 840 c.

15. Фразеологічний словник української мови : у 2 кн. / уклад. В.М. Білоноженко та ін. Київ : Наукова думка, 1893. Кн. 1.528 с. Кн. 2. С. 529-980.

16. Фразеологічний словник. URL: http://svitslova.com/idiomsdictionary.html.

17. Ханикіна Н.В. Методика поліситуаційно-ономасіологічного аналізу мотивації дієслівної семантики фізичного і психічного станів суб'єкта. Вісник Київського наиіонального лінгвістичного університету. Серія: Філологія. 2015. Т. 18. № 2. С. 185-202.

18. A magyar nyelv értelmező szótára. URL: http://mek.oszk.hu/ adatbazis/magyar-nyelv-ertelmezo-szotara/elolap.php (дата звернення: 02.12.2020).

19. Magyar szalások közmondások abatbáziso. URL: https:// baranyilaszlozsolt.com/pciskola/TAMOP-4_2_5-09_Magyar_ szolasok_kozmondasok_adatbazisa.pdf(дата звернення: $0 \overline{2} .12 .2020$ ).

Sokolets I., Khanykina N. Motivational basis of verbs denoting psycho-emotional state of being in love/feeling affection in Ukrainian and Hungarian languages

Summary. The paper deals with the investigation of semantic, word-formational, cognitive, and onomasiological mechanisms denoting a person's physical and mental state of being in love/feeling affection, expressed by Ukrainian and Hungarian verbs.

The objectives of this research are the identification of the nature of motivational relations inherent in the onomasiological, cognitive, and semantic structure of verbs that denote a person's mental state of being in lovelfeeling affection, the analysis of the above-mentioned verbs from the stand- 
point of cognitive onomasiology, and the identification of their motivational types in Ukrainian and Hungarian.

To achieve the aim of the study, we employed the polysituational analysis, first described by N. Lebedeva and her disciples M. Nebolsyna, S. Kamzina, and others. Polysituational analysis allowed the authors to establish the zones of nuclear semantics and its periphery - inner, far, and outer - within the lexical-semantic group of verbs denoting a person's mental state, namely the state of being in love, in Ukrainian and Hungarian. The proposed research method is based on the concept which presents the verb as a poly-situational, poly-actional, and poly-propositional structure, which allows representing the verb semantics as a situatheme - a special structure that reflects the dynamics of the verb content.

The research procedure was aimed at determining the etymology of the verbs denoting a person's psycho-emotional state of being in love/feeling affection in Ukrainian and Hungarian, and defining their asserthemes, as well as situathemes of inner, far, and outer peripheries, and a con-situation. The types of motivational bases for the verb semantics of "love" were established with the help of the poly-situational verb analysis and identification of the nuclear-peripheral zone of the situathemes.

The results of the research allowed us to identify the motivational types of a person's psycho-emotional state of being in lovelfeeling affection in Ukrainian and Hungarian, that is, mixed motivation, which combines modus and sensory-psychological types, and gestalt sub-type of the associative-terminal type of motivation with dominant sublimated (ethic and aesthetic) positive estimation.

Key words: assertheme, inner, far and outer periphery, con-situation, situatheme, situational-actional-propositional approach, poly-situational analysis. 